\title{
頸部脊䯣症に対する再手術例の検討
}

\author{
久留米大学医学部整形外科 \\ 今里 博 司・永田見生 \\ 大 橋 輝 明・井上 明 生
}

\section{The Multiply Operated Neck with Cervical Myelopathy}

by

\author{
Hiroshi Imasato, Kensei Nagata, \\ Teruaki Ohashi and Akio Inoue
}

Department of Orthopaedic Surgery, Kurume University School of Medicine, Kurume

\begin{abstract}
We will report on twenty-eight case studies of patients with recurrent cervical myelopathy who underwent reoperations between 1980 and 1991. They consisted of 19 patients with cervical spondylotic myelopathy and 9 patients with OPLL. At first operation, 26 patients had anterior fusions, and 2 patients had laminectomies. Of the 26 anterior fusion qroup, anterior fusions at the adjacent intervertebral level were performed on 8 patients, expansive laminoplasties on 15 patients, and laminectomies on 3 patients. Anterior fusions were performed on the 2 laminectomy patients. The causative factors of the reoperations were as follows: -14 patients $(50 \%)$ had a cord compression at the ajacent level, 4 had canal stenosis, 4 had insufficient decompression, 3 had a progression of the OPLL, 2 had a kyphotic deformity, and had a traffic accident. In our follow-up studies over an average of 2 years and 9 months, excellent and good results were obtained in 11 patients $(39 \%)$, poor in 10 , unchanged in 5 , and worse in 2 .

From these results, we conclude that the operative procedures and levels of cervical myelopahy should be decided after an accurate neurological and image evaluation of the affected levels.
\end{abstract}

\section{はじめに}

頝部脊骨迶症に対する手術結果が不満足であったり， 経過中に症状の再発をきたしたために再手術を必要と する症例をときに経験する．今回我々は，再手術例の 病態および術後成績などについて検討したので報告す る.

\section{症例}

症例は 1980 年より 1991 年までに当科において䅡部 脊髄症の診断で再手術を必要とした 28 例で, 男性 21 例，女性 7 例，平均年龄 54 才である. そのうち，当 科で初回手術を行なったのは 24 例である. 疾患の内 訳は, 頚椎症（含椎間板ヘルニア）19例, 後縦靶帯 骨化症 9 例であった. 初回手術より再手術までの平均 期間は 4 年 9 カ月（1 カ月〜 17 年）であり, 再手術
後の平均経過観察期間は 2 年 5 力月（ 6 力月～ 10 年 $)$ である。

\section{結果}

初回手術方法は前方固定術が 26例に, 椎弓切除術 が2 例に施行されていた．再手術方法としては前方固 定術群の 8 例に前方固定術を，15 例に春柱管拡大術 を 3 例に椎弓切除術を施行し, 椎弓切除術群 2 例は前 方固定術を施行した（表 1 ）.

表 1 手術方 法

\begin{tabular}{|c|c|c|c|c|}
\hline \multirow[t]{2}{*}{ (初回手術) } & \multicolumn{4}{|c|}{ (再手術) } \\
\hline & & & 前方固定術 & 8 例 \\
\hline \multirow[t]{2}{*}{ 前方固定術 } & 26例 & $\Rightarrow$ & 㓌柱管拡大術 & 15例 \\
\hline & & & 椎弓切除術 & 3 例 \\
\hline 椎弓切除術 & 2 例 & $\Rightarrow$ & 前方固定術 & 2 例 \\
\hline
\end{tabular}


再手術の原因としては，隣接椎間の障害によるもの が, 14 例 $(50 \%)$ と最も多く, 次いで尙柱管狭窄と 除圧不充分によるもの各々 4 例 $(14.3 \%)$, OPLLの 進展 3 例, 後弯变形 2 例, 不慮の外傷 1 例であった (表 2).

表 2 再手術の原因

\begin{tabular}{ll}
\hline \hline 1. 隣接椎間の障害 & 14 例 $(50 \%)$ \\
2. 疽柱管狭矣 & 4 例 $(14.3 \%)$ \\
3. 除圧不足 & 4 例 $(14.3 \%)$ \\
4. OPLL 進展 & 3 例 $(10.7 \%)$ \\
5. 後弯変形 & 2 例 $(7.1 \%)$ \\
6. 不慮の外傷 & 1 例 $(3.6 \%)$ \\
\hline
\end{tabular}

隣接椎間の障害 14 例を retrospective にみると, 初 回手術時すでに隣接椎間の異常可動性や䅡椎全体の malalignment 等の異常を認めたものは10 例であった。 4 例は初回異常を認めず新たな佥髄圧迫であった。そ れらの高位は, 上位椎間 11 例, 下位椎間 3 例であった。 隣接椎間の再手術までの期間は平均 5 年 4 力月 $(10$ 力 月〜 17 年) であった（表 3 ). 前方法の隣接椎間の変 化を術前後の MRI 所見で見た当科の最近の調查では, 術後平均 10 力月の MRI で新たな春髄圧迫および圧迫 程度の増加を来したものは 56 例中 19 例 (34\%)であっ た（表 4 ）。

表 3 隣接椎間の障害 (14例)

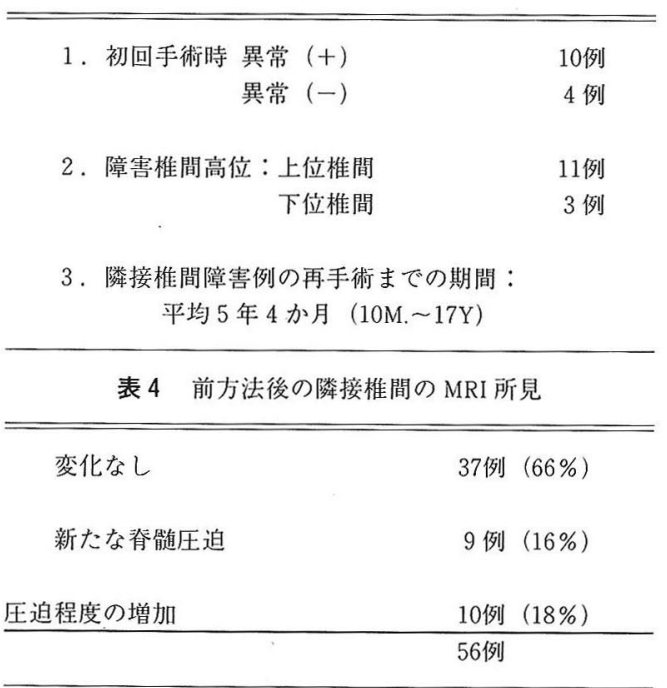

再手術後の術後成績を平林の改善率で見てみると優 と良を合わせて $39.3 \%$ ，不変・悪化例 $25 \%$ で平均改 善率は $42.1 \%$ であった。これらは当科の澒部脊髄症
全体の術後成績の平均 $60.4 \%$ に比較して劣っていた (図 1 ).

図 1 術 後 成 績

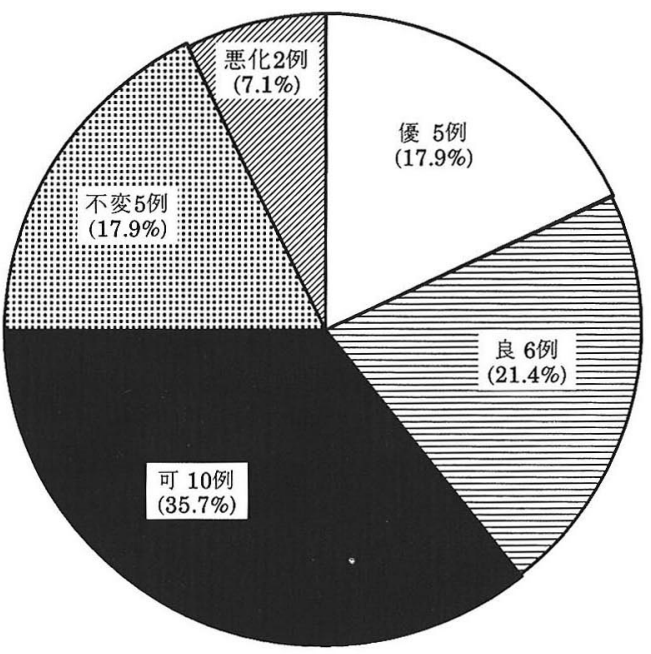

平均改善率 $42.1 \%$

60 歳 男性

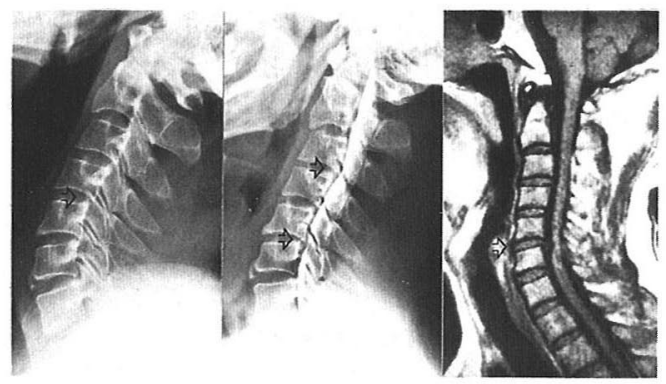

初回手術前

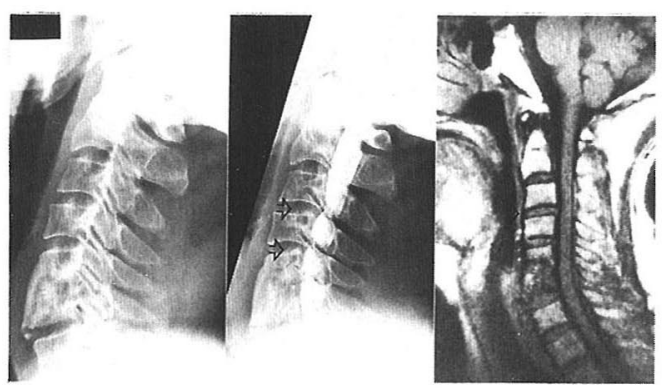

術後 1 年

図 2 初回手術時：C 4 後方すべり， $C_{5 / 6}, C_{3 / 4}$ 間の圧迫 あり術後 1 年 : $\mathrm{C}_{3 / 4}, \mathrm{C}_{4 / 5}$ 間の圧迫認める 
成績不良例としては，悪化例は motor neuron disease 及び HAM の合併疾患をもった 2 例と不変例は再 手術原因が隣接椎間の悪化であった 2 例と，高度脊柱 管狭窄が原因であった 3 例である。

症例を供覧する. 60 才，男性. 両上肢の痛みと歩 行障害を主訴に初診する。初回手術前の単純 X 線像で $\mathrm{C}_{4}$ の後方すべり，ミエログラフィーにて $\mathrm{C}_{5 / 6}$ 間の高 度の前方圧迫， $\mathrm{C}_{3 / 4}$ 間の軽度の前方圧迫を認め, MRI では $C_{5 / 6}$ 間で椎間板へルニアによる spinal cord の圧 迫を認めた。 $C_{5 / 6}$ 間の前方固定術を施行し，術前 JOA score は 5 点から 7 点に改善するも，両上肢の痛 み，しびれ残存するため 1 年後再入院する. myelography, MRI にて $\mathrm{C}_{3 / 4}, \mathrm{C}_{4 / 5}$ 間に椎間板へルニ アによる春髄圧迫を認め，脊柱管拡大術を施行した。 術後 1 年 3 力月の現在, JOA score は 10 点に改善し たが，初回手術時の固定範囲に問題があった症例であ る(図 2 ).

\section{考察}

頝部脊髄症の術式選択では現在，脊柱管狭窄があれ ば後方法，春柱管狭窄がなく前方圧迫因子が $1 \sim 2$ 椎 間に限定される場合には前方法というある程度の判断 基準が既に得られているが，なお選択に迷うことも多 い. 今回我々の 28 例の再手術例の原因としては, 前 方固定術後の隣接椎間の障害が 14 例 (50\%) と最も 多く,そのうち 10 例は初回手術時すでに隣接椎間に 異常可動性などの病変が認められ，前方法では固定範 囲の慎重な検討が重要と思われた。しかし隣接椎間に
異常のない症例にも発症することがあり未だ問題を残 すところである．再手術原因が夷柱管狭窄と考えられ た 4 例のうち 3 例は再手術後の成績は不良であり, 初 回手術時の術式選択に問題があったと思われた.

頝部脊骾症はその発生および病態が複雑であり，い まだ充分に解明されたとはいい難い。また，諸家の報 告からも多数回手術例では満足すべき結果が得られる ことは少ない1）2．初回手術時の術式選択に当って は病態の充分な把握により, 多数回手術を予防するこ とが大切である。

\section{ま と め}

1. 頚部脊骾症に対する再手術 28 例について検討 した

2. 再手術の原因としては, 前方固定術後の隣接椎 間の障害が 14 例 $(50 \%)$ と半数を占めそのうち初回 手術時異常を認めたものは10 例，異常を認めなかっ たのは 4 例であった。

3. 術式選択に当っては頚椎可動性, 脊柱管狭窄, 病変椎間数などを十分検討し前方法か後方法の選択お よびその範囲を決定すべきである.

\section{参 考 文 献}

1）里見和彦他：頚椎性脊䯣症における多数回手術例 (MON) の検討と予防上の留意点, 臨整外, 21： 785-796, 1986

2) 柴田 稔: 頚部脊髄症複数回手術例の検討, 臨整外, $21: 821-828,1986$. 